\title{
UNPOPULAR SPECIES AND THEIR INCREASED USE IN THE MARITIMES ${ }^{1}$
}

\author{
BY H. D. HEANEY ${ }^{2}$
}

\begin{abstract}
Full utilization of all species will only be realized when a greater demand for goods is developed by a vastly increased population. The paper points out that the utilization of accessible Maritime timber is twice as intensive as that for Canada as a whole.

After a short discussion of the popularity of some species in the past, the wood-using industries are selected as the group from whose point of view the popularity of species should be appraised. It is mentioned that some species popular with this group might not be so well-liked by silviculturists or administrators of forest lands.

Using stumpage rates as a criterion of popularity-the lower the rate the less popular the species-the unpopular species in the Maritimes are listed as follows: beech, the intolerent hardwoods, tamarack and jack pine. The possibilities of increased utilization of these species are discussed with the increased use of hardwoods being recognized as the main problem in the Maritimes.

In the course of recent flights over the Maritimes, I was struck by the tremendous expanse of forests. It was clearly evident that the structure of these forests was the result of fires, insects and disease, with little evidence showing of man's cultural efforts. I would ask you to imagine another kind of forest here, with species growing on suitable sites, all well protected and managed, and with all products properly utilized. Such a forest must be our ultimate goal. When can we hope to reach it? None of us knows, but I believe that, before any great progress can be made, there must be the compulsion of a greater demand for work and goods from a vastly increased population. We must have in the Maritimes, and in the rest of Canada, a great increase in the ratio of people to trees, before full utilization of all species is possible.

Before going on to discuss popularity and utilization of specific species, I wish to point out what was to me a rather surprising fact about the production from Maritime forests. With 5 per cent of the accessible timber in Canada, the Maritime Provinces account for over 10 per cent of Canadian primary forest production. The reason for this is not immediately clear. There are three factors, one or all of which might provide an explanation. First, although the figures are for accessible timber for both the Maritimes and Canada, Maritime forests are generally the more accessible. Another fact that might help to explain the difference is that occupied Crown lands form only 36 per cent of the forested land in the Maritimes compared to 67 per cent for Canada as a whole. The third factor, and this ties in with my previous assumption about population, is that the average population is 25 people per square mile in the Maritimes, and only six and a half for all Canada.

${ }^{3}$ Paper presented at the 48th Annual Mecting of the C.I.F. held on October 2-5, 1956 in Chicoutimi, P.Q.

'Federal Forestry Branch, Department of Northern Affairs and Natural Resources,

Fredericton, N.B.
\end{abstract}


In discussing the popularity of particular species of trees, we should first consider the point of view. Lucretius said "What is food to one may be fierce poison to others", or as we usually hear it "One man's meat is another man's poison".

As the theme of our meeting is Increased Utilization we are right, I believe, in appraising the popularity of species from the viewpoint of the first consumers, the wood using industries. No doubt we would get a different opinion from the silviculturist or the administrator of forest lands.

Although balsam fir has been popular as a pulpwood species since the 1920's, it is unpopular now with the silviculturist and administrator. The reason for this is the cost of fighting the budworm attack which is still at full strength. The balsam wooly aphid also contributes to the dislike of balsam fir. Although less spectacular and violent than the budworm in its damage, the wooly aphid could be more disastrous in its final effects.

The preference of wood-users for various species has changed over the years with the discovery of new uses for wood and with the development of new markets. We are concerned here with the present and future, but we might take a backward glance to see how preferences have changed. We may see just as significant changes in the future.

During the eighteenth and early nineteenth centuries, large forest areas in the Maritimes were reserved as a source of masts for the Royal Navy. Before land settlement became extensive, white pine was the only truly popular species for export. Throughout the late nineteenth century and until the 19.20's, the pines and spruces were cut for lumber, and hemlock was cut for bark. The tolerant hardwoods, yellow birch, maple and beech were used in large quantities only as fuel. It was not until the pulpwood industry was firmly established that balsam fir became popular. Considering the quantities available, jack pine was little utilized until an export market for pit props was developed in the United Kingdom late in the 1930's. Production in New Brunswick rose to a maximum of 250,000 cords in 1941 , but it has decreased until at present only 16,000 cords are cut for pit props, two-thirds of which are jack pine.

As the popularity of certain species waxed and waned in the past, so it can in the future.

How are we to assess the popularity of species in the Maritimes now? Two methods come to mind at once. By talking with wood users, we can get their opinions, or we can compare actual utilization of a species with the quantities of that species available in the forest. The former method has the disadvantage of being subjective and controversial, while we are apt to become involved in a maze of sometimes conflicting statistics in using the latter. I have tried a different approach. I have assumed that a comparison of the selling price of standing trees will indicate degrees of popularity-the lower the stumpage, the less popular the species.

In Nova Scotia there is no published schedule of stumpage dues from Crown lands, but the money received per unit of various species in timber 
sales follows the same general trend as is found when one examines the published rates for various species sold from Crown lands in New Brunswick. We shall examine a few of these rates.

The stumpage rates for softwood sawlogs in New Brunswick vary from a low of seven dollars per thousand board feet for hemlock to a high of nine dollars for white pine. This small difference might not be considered significant in appraising the popularity of softwood species for sawlogs. I will mention another fact about hemlock later which might justify us in considering it an unpopular species in New Brunswick but not in Nova Scotia.

The stumpage rate for jack pine and tamarack pulpwood is three dollars per cord, while that for spruce and fir is four dollars and fifty cents per cord or fifty per cent more. There is no published rate in New Brunswick for hemlock pulpwood and actual production is very low. We can be fairly sure then that jack pine, tamarack and hemlock are unpopular for pulpwood in New Brunswick. The same applies to Nova Scotia, with the exception of hemlock, which is used in fairly large quantities.

The stumpage rates for hardwood sawlogs vary from eight dollars per thousand for yellow birch to four dollars for beech. In descending order the popularity of hardwood species for sawlogs is yellow birch, hard maple, white birch and poplar, and beech. The stumpage rate for hardwood cordwood of all species is one dollar per cord, as compared to a range of three to four and a half dollars for softwood. We can definiteiy state that all hardwood cordwood is unpopular. In practice hardwood cordwood includes the poorer grades of the tolerant hardwoods, yellow birch, hard maple and beech and the intolerant hardwoods, the aspens and white birch. The unpopularity of hardwood, deduced from these New Brunswick stumpage rates, is confirmed for Nova Scotia where the average stumpage received in sales of hardwood is less than one-half that of softwood.

The unpopular species in the Maritimes then are beech, the intolerant hardwoods, tamarack, and jack pine. To this might be added hemlock for New Brunswick. Comparatively rare species of little economic significance have not been considered. Of the unpopular species beech and tamarack present no great problem as the quantities now available in Maritime forests are comparatively small. We should consider then the possibilities of increasing the use of jack pine, hemlock and hardwood cordwood.

Jack pine is not an important forest tree in the Maritimes except in eastern New Brunswick and, to a lesser extent. Cumberland County in Nova Scotia. It is in northeastern New Brunswick that large base metal mining properties are being developed. This hard rock mining does not require the large quantities of supporting timbers and props necessary in coal mining, but there should be sufficient increased demand for mining timbers to stimulate the production of jack pine for this purpose. About 80,000 cords of props and timbers are used annually in the coal mines of Nova Scotia. Perhaps a larger proportion of jack pine could be utilized. 
Hemlock is used to a comparatively much greater degree for pulpwood in Nova Scotia than in New Brunswick. It has always been in disfavor as a lumber species except for rough boarding and dimension timber in the construction of bridges and wharves. It would seem that the greatest chance for increased use would be as pulpwood, where there are no technical objections to its use. Some inducement in price might have to be offered by administrators of forest lands.

From a perusal of stumpage values we have concluded that intolerant hardwoods for any use, and hardwood cordwood of all species, are unpopular. This is confirmed when actual production is compared with quantities available.

In New Brunswick approximately 1,625,000 cunits of softwood are produced from all forest lands annually. A little more than 25 per cent of this amount, or 460,000 units of hardwood, are cut. Of this amount 300,000 cunits are produced for fuel, which will decrease, 75,000 cunits for sawlogs, 65,000 for pulpwood and 20,000 cunits for ties, veneer and squares. In order that hardwoods be utilized as intensively as softwoods, it would be necessary to nearly double hardwood production.

The main problem in the Maritimes then is to increase our utilization of the intolerant hardwoods and the poorer grades of other hardwood species. From talks with wood users and government officials in New Brunswick and Nova Scotia, one forms the opinion that there will be no significant increase in utilization unless mills at present producing Kraft pulp use more hardwood, or unless semi-chemical or chemi-ground pulp is produced in new mills. Another use would be in the manufacture of hardboards or particle boards, for which there seems no immediate prospect. I understand that there is no technical barrier to the increased use of hardwood for several kinds of pulp. The aspens, formerly weed species in the Lake States, have now passed softwood in pulpwood production.

There is now the distinct possibility of two new pulp and paper mills in the Maritimes, one in southern New Brunswick in the Lepreau area and another in Nova Scotia near Pictou. If promotional efforts now being made are successful, both of these mills will be consumers of large quantities of hardwood pulpwood. This would go far towards solving our hardwood problem.

The stumpage rate of one dollar per cord for hardwood in New Brunswick, which was mentioned before, is a new rate in effect only since the first of August, and is a reduction of one dollar and a half per cord. This was a constructive step to encourage hardwood production. 